\title{
Perbandingan Arachis pintoi dengan Jenis Tanaman Penutup Tanah Lain sebagai Biomulsa di Pertanaman Kelapa Sawit Belum Menghasilkan
}

\section{Comparing Arachis pintoi versus Other Cover Crops as Biomulch in Immature Oil Palm Plantations}

\author{
Yuniarti $^{1,2}$, M. Achmad Chozin ${ }^{3 *}$, Dwi Guntoro ${ }^{3}$, dan Kukuh Murtilaksono ${ }^{4}$ \\ ${ }^{1}$ Program Studi Agronomi dan Hortikultura, Sekolah Pascasarjana, Institut Pertanian Bogor \\ ${ }^{2}$ Program Studi Agroteknologi, Fakultas Pertanian dan Peternakan, Universitas Islam Negeri Sultan Syarif Kasim Riau \\ ${ }^{3}$ Departemen Agronomi dan Hortikultura, Fakultas Pertanian, Institut Pertanian Bogor \\ (Bogor Agricultural University), Jl. Meranti, Kampus IPB Darmaga, Bogor 16680, Indonesia \\ ${ }^{4}$ Departemen Ilmu Tanah dan Sumber Daya Lahan, Fakultas Pertanian, Institut Pertanian Bogor \\ (Bogor Agricultural University), Jl. Meranti, Kampus IPB Darmaga, Bogor 16680, Indonesia
}

Diterima 4 Mei 2017/Disetujui 3 Januari 2018

\begin{abstract}
Cover crops have the same role as biomulches to maintain soil moisture and reduce the evaporation of soil water. The objective of research was to compare Arachis pintoi versus other cover crops as biomulch in immature oil palm plantations. The study was conducted in the Field of Education and Research Palm IPB-Cargill, Jonggol, Bogor starting in December 2014 until May 2015. The experiment was designed according to a randomized block design with four replications. The treatments were cover crop species (biomulch) i.e. no biomulch/natural vegetation, Arachis pintoi Karp. \& Greg., Centrosema pubescens Benth., Calopogonium mucunoides L. and Pueraria javanica Benth. Planting materials used were cutings of $\underline{A}$. pintoi and seed of $\underline{C}$. pubescens, $\underline{C}$. mucunoides and $\underline{P}$. javanica. The planting material were planted in plots $9 \mathrm{~m} x 3 \mathrm{~m}$ and plot for biomass $1 \mathrm{~m} \times 1 \mathrm{~m}$. The results showed that the A. pintoi was not significantly different from other biomulches for ground covering and capability to hold water. Soil water content in the treatment of $\underline{A}$. pintoi biomulch was not different from other biomulch treatments.
\end{abstract}

Keywords: biomass production, cover ground, soil depth, soil water content

\section{ABSTRAK}

Tanaman penutup tanah berperan sama dengan biomulsa untuk menjaga kelembaban tanah serta mengurangi penguapan air tanah. Tujuan penelitian adalah membandingkan Arachis pintoi dengan jenis tanaman penutup tanah lain sebagai biomulsa di pertanaman kelapa sawit belum menghasilkan. Penelitian dilakukan di Kebun Pendidikan dan Penelitian Kelapa Sawit IPB-Cargill Jonggol, mulai bulan Desember 2014 sampai dengan Mei 2015. Percobaan menggunakan rancangan acak kelompok dengan empat ulangan. Perlakuan berupa jenis biomulsa, yaitu tanpa biomulsa/vegetasi alami, Arachis pintoi Karp. \& Greg., Centrosema pubescens Benth., Calopogonium mucunoides L. dan Pueraria javanica Benth..

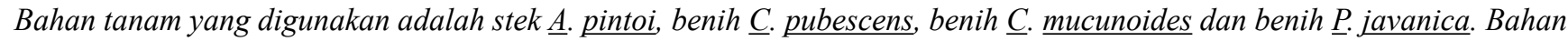
tanam tersebut ditanam pada plot $9 \mathrm{~m} \times 3 \mathrm{~m}$ dan plot pengukuran biomassa $1 \mathrm{~m} \times 1 \mathrm{~m}$. Hasil penelitian menunjukkan bahwa A. pintoi sebagai biomulsa tidak berbeda dengan perlakuan biomulsa lainnya dalam hal penutupan tanah dan kemampuan menahan air tanah. Kadar air tanah pada perlakuan biomulsa $\underline{\text { A }}$ pintoi tidak berbeda dengan perlakuan biomulsa lainnya.

Kata kunci: kadar air tanah, kedalaman tanah, penutupan tanah, produksi biomassa

\section{PENDAHULUAN}

Perkebunan kelapa sawit banyak mendominasi lahanlahan dengan kondisi tanah marjinal. Tanah marginal memiliki karakteristik fisika dan kimia yang tingkat kesuburan tanahnya rendah dan kurang menguntungkan

\footnotetext{
* Penulis untuk korespondensi. e-mail: ma_chozin@yahoo.com
}

untuk pertumbuhan tanaman, akibatnya ketersediaan air untuk tanaman menjadi terganggu (Farni et al., 2012). Perkembangan luas areal perkebunan kelapa sawit berdampak nyata terhadap lingkungan, diantaranya semakin berkurangnya ketersediaan air. Tanaman kelapa sawit secara ekologis merupakan tanaman yang membutuhkan banyak air dalam proses pertumbuhannya, yaitu sekitar 4.10-4.65 mm per hari (Widodo dan Dasanto, 2010). Akan tetapi kebutuhan air tanaman ini masih lebih sedikit jika 
dibandingkan dengan kebutuhan air pada tanaman kelapa dan tanaman hutan (Pasaribu et al., 2012).

Salah satu faktor yang menentukan produktivitas lahan kering adalah ketersediaan air tanah yang sangat tergantung pada curah hujan sebagai sumber air utama (Wahyunie et al., 2012a). Ketersediaan air dalam tanah sangat mempengaruhi pertumbuhan tanaman secara langsung. Ketersediaan air tanah tersebut dapat berubah sesuai dengan faktor yang mempengaruhinya. Kadar air tersedia dalam tanah akan berbeda karena sifat tanah yang berkembang pada masing-masing lokasi juga berbeda (Nita et al., 2014). Dengan demikian, dibutuhkan upaya untuk mengimbangi ketersediaan air tanah pada perkebunan kelapa sawit di lahan kering.

Menurut Arsyad (2012) salah satu cara paling efektif untuk memelihara permukaan tanah agar mudah menyerap dan menahan air melalui penutupan tanah dengan mulsa. Hasil penelitian Wakhid et al. (2012) menunjukkan bahwa pemberian mulsa serasah (bagian tanaman yang telah mati) tanaman dapat menjaga kadar air tanah dari proses penguapan sehingga kebutuhan tanaman akan kadar air tanah terutama pada musim kering dapat terjamin. Pemberian mulsa serasah juga dapat menghambat pertumbuhan gulma yang mengganggu tanaman sehingga konsumsi air berkurang. Penggunaan mulsa pada tanaman semusim dapat digantikan dengan tanaman penutup tanah pada perkebunan dengan tujuan yang sama.

Tanaman penutup tanah mempunyai peran yang sama dengan mulsa, selain untuk menurunkan suhu tanah, mengurangi penguapan dari tanah, tanaman penutup tanah juga dapat mempertahankan kelembaban tanah pada musim kering (Asbur dan Ariyanti, 2017), memperbaiki cadangan air tanah, mengurangi tingkat perkolasi dan runoff (Ariyanti et al., 2016a). Tanaman penutup tanah secara efektif juga dapat meminimalkan erosi dan mengurangi kehilangan C organik, N, P, dan K (Asbur et al., 2016), serta dapat menekan perkembangan gulma pada lahan budidaya (Sumiahadi, 2014).

Tanaman yang biasa digunakan sebagai biomulsa adalah jenis tanaman legum atau kacang-kacangan. Penelitian tentang potensi tanaman legum sebagai biomulsa telah banyak dilakukan, akan tetapi belum ada yang melaporkan penggunaan tanaman Arachis pintoi sebagai biomulsa di pertanaman kelapa sawit serta perannya dalam mempertahankan kadar air tanah di pertanaman kelapa sawit. A. pintoi merupakan tanaman hias yang diintroduksi menjadi biomulsa sehingga masih mempunyai kekurangan dalam hal kecepatan pertumbuhannya pada saat awal pertumbuhan (Sumiahadi et al., 2016). Hasil penelitian Chozin et al. (2014) menunjukkan bahwa perlakuan biomulsa $A$. pintoi 70 dan 49 hari sebelum tanam mampu meningkatkan komponen pertumbuhan dan produksi buah tomat. Sumiahadi (2014) juga menyatakan bahwa penggunaan biomulsa $A$. pintoi dapat menekan laju erosi hingga lebih dari $70 \%$ dibandingkan dengan perlakuan tanpa mulsa dengan penyiangan pada pertanaman jagung. Penelitian ini bertujuan untuk membandingkan $A$. pinto $i$ dengan jenis tanaman penutup tanah lain sebagai biomulsa di pertanaman kelapa sawit belum menghasilkan.

\section{BAHAN DAN METODE}

Penelitian dilaksanakan di Kebun Pendidikan dan Penelitian Kelapa Sawit IPB-Cargill Jonggol (06 ${ }^{\circ} 28.289^{\prime}$ LS $107^{\circ}$ 01.329' BT) dengan elevasi $108 \mathrm{~m}$ di atas permukaan laut, merupakan lahan marginal bertekstur tanah liat dan kandungan C-organik sedang. Nilai kadar air pada kapasitas lapang dan titik layu permanen masing-masing adalah $31.81 \%$ volume dan $22.99 \%$ volume. Nilai tersebut diperoleh berdasarkan hasil laboratorium dengan cara penetapan kurva pF $2.54\{[$ (bobot basah tanah pada $\mathrm{pF} 2.54$ - bobot kering tanah) / bobot kering tanah] x 100\% x bobot isi tanah $\}$ dan penetapan kurva pF $4.2\{[$ (bobot basah tanah pada $\mathrm{pF} 4.2$ - bobot kering tanah) / bobot kering tanah] $\mathrm{x}$ $100 \% \mathrm{x}$ bobot isi tanah $\left.\left(1.19 \mathrm{~g} \mathrm{~cm}^{-3}\right)\right\}$. Penelitian dilakukan satu kali, pada saat tanaman kelapa sawit TBM II. Analisis tanah awal dilakukan di Laboratorium Departemen Ilmu Tanah dan Sumberdaya Lahan, Fakultas Pertanian, IPB, Bogor. Penelitian dimulai bulan Desember 2014 sampai dengan Mei 2015.

Bahan penelitian yang digunakan antara lain bibit dari stek batang Arachis pintoi, benih Calopogonium mucunoides, Centrosema pubescens dan Pueraria javanica, pupuk NPK, pupuk kandang, Rootone-F, dan Rhizobium. Peralatan yang digunakan antara lain neraca analitik, oven, kuadran, peralatan pengukur kadar air (bor tanah kecil, aluminium foil), dan alat penunjang lainnya.

Penelitian dilakukan menggunakan rancangan acak kelompok (RAK) dengan 4 ulangan. Perlakuan terdiri atas tanpa biomulsa/vegetasi alami (M0), biomulsa Arachis pintoi (M1), Centrosema pubescens (M2), Calopogonium mucunoides (M3), dan Pueraria javanica (M4).

Stek bagian tengah $A$. pintoi yang dipotong berukuran empat ruas diberi perlakuan Rootone $\mathrm{F}$ dengan konsentrasi 600 ppm (600 mg L-1 air) sebelum dibibitkan selama satu bulan. Perlakuan benih berupa perendaman benih dalam air hangat selama 2 jam pada suhu $75^{\circ} \mathrm{C}$ dilakukan pada benih biomulsa lain, kemudian diinokulasikan dengan rhizobium dengan dosis $10 \mathrm{~g} \mathrm{~kg}^{-1}$.

Lahan dibersihkan dari gulma dan dibentuk plot di dalam gawangan kelapa sawit. Terdapat dua jenis plot pada gawangan terpisah; untuk pengamatan non destruktif, plot dibentuk dengan ukuran $9 \mathrm{~m}$ x $3 \mathrm{~m}$ sebanyak 5 plot per kelompok dengan total keseluruhan 20 plot. Kelompok merupakan gawangan kelapa sawit. Jarak antar plot dalam kelompok adalah $1 \mathrm{~m}$ dan jarak antar kelompok adalah barisan tanaman kelapa sawit.

Plot untuk pengamatan destruktif biomassa berbagai jenis biomulsa dibentuk dengan ukuran $1 \mathrm{~m} \mathrm{x} 1 \mathrm{~m}$ dengan 3 ulangan untuk masing-masing perlakuan dan 4 kali pengamatan destruktif. Jarak antar ulangan $0.5 \mathrm{~m}$ dan jarak antar perlakuan $0.5 \mathrm{~m}$. Lahan diberi pupuk kandang dengan dosis 5 ton ha $^{-1}$. Pemupukan NPK dilakukan pada saat tanaman berumur 6 MST dengan dosis $100 \mathrm{~kg} \mathrm{ha}^{-1}$. Pemeliharaan tanaman dilakukan sesuai kebutuhan.

Persentase penutupan tanah dihitung dengan menggunakan kuadran $0.5 \mathrm{~m}$ x $0.5 \mathrm{~m}$ di grid yang dilempar secara acak sebanyak dua kali pada setiap plot. Pengamatan produksi biomassa dilakukan dengan menimbang bobot 
kering tanaman pada plot dengan luasan satu meter persegi yang dilakukan setiap bulan selama 4 bulan dengan menimbang semua bagian tanaman (akar dan tajuk) setelah tanaman dioven selama 2 hari dengan suhu $80^{\circ} \mathrm{C}$.

Pengamatan perubahan air tanah mingguan ( 3 hari dalam seminggu) dilakukan dengan pengukuran kadar air tanah menggunakan metode gravimetrik. Metode gravimetrik merupakan persentase dari perbandingan selisih antara bobot basah dan kering tanah dengan bobot kering tanah. Pengambilan sampel tanah menggunakan bor tanah berukuran kecil dengan diameter $2 \mathrm{~cm}$ dan panjang $50 \mathrm{~cm}$ yang dibenamkan ke tanah pada kedalaman $0-10 \mathrm{~cm}$ dan 10-20 cm. Pengambilan sampel tanah dilakukan pada 2 titik dalam unit percobaan dengan 2 ulangan, terdapat 192 titik pengambilan sampel tanah pada keseluruhan petak percobaan. Sampel tanah yang diambil kemudian dioven pada suhu $105{ }^{\circ} \mathrm{C}$ selama 24 jam untuk mendapatkan nilai kadar air tanah. Air yang hilang karena pemanasan merupakan air yang terdapat dalam tanah basah. Data curah hujan harian diperoleh dari Kebun Pendidikan dan Penelitian Kelapa Sawit IPB-Cargill Jonggol. Pengamatan curah hujan dilakukan dengan menggunakan alat pengukur curah hujan Ombrometer Observatorium (OBS).

\section{HASIL DAN PEMBAHASAN}

\section{Hubungan Kadar Air Tanah dengan Berbagai Jenis Biomulsa dan Curah Hujan}

Hasil sidik ragam menunjukkan terdapat keragaman kadar air tanah yang nyata pada 11 MST dan 20 MST (Tabel 1). Pada 11 MST biomulsa $A$. pintoi dapat menahan kadar air tanah lebih tinggi berbeda nyata terhadap biomulsa $C$. pubescens dan C. mucunoides dengan kondisi curah hujan lebih rendah daripada minggu sebelumnya. Perlakuan tanpa biomulsa/vegetasi alami mempunyai kadar air tanah paling rendah berbeda nyata terhadap semua jenis biomulsa pada 20 MST. Ini menunjukkan bahwa pada saat tidak terjadi hujan, perlakuan dengan biomulsa lebih mampu menahan ketersediaan air tanah dibandingkan perlakuan tanpa biomulsa atau vegetasi alami.

Pola perubahan kadar air tanah pada berbagai jenis tanaman penutup tanah sangat fluktuatif dan mengikuti pola curah hujan meskipun tidak terjadi pada keseluruhan pengamatan (Gambar 1). Kadar air tanah selama periode pertumbuhan tanaman berfluktuasi dengan pola yang sama pada kedua kedalaman setiap perlakuan. Nilai kadar air tanah pada perlakuan tanpa biomulsa atau vegetasi alami (M0) cenderung lebih rendah dibandingkan dengan perlakuan menggunakan biomulsa. Hal ini sejalan dengan penelitian Hamdani (2009) pada tanaman kentang; Asbur dan Ariyanti (2017) pada tanaman kelapa sawit yang menyatakan bahwa tanaman penutup tanah atau mulsa dapat mempertahankan kelembaban tanah. Wahyunie et al. (2012b) menambahkan bahwa tanaman penutup tanah juga dapat mengurangi laju evaporasi dan meningkatkan laju infiltrasi minimum/ kapasitas infiltrasi. Lebih lanjut, Santosa et al. (2018) menyatakan bahwa penggunaan mulsa dapat mengurangi konsumsi air virtual abu-abu pada kebun sawit.

Kadar air tanah menurun drastis pada 12-14 MST mengikuti pola penurunan curah hujan. Akan tetapi pada saat curah hujan meningkat pada 14-15 MST, kadar air tanah juga mengalami peningkatan drastis melebihi nilai kadar air tanah sebelumnya (Gambar 1). Hal ini dapat terjadi karena kemampuan tanah menahan air dengan adanya biomulsa, sehingga dengan penambahan curah hujan pada minggu berikutnya terjadi peningkatan akumulasi kadar air tanah. Pada 15-16 MST kadar air tanah menurun pada saat curah hujan meningkat, kondisi ini dapat disebabkan oleh kebutuhan biomulsa dan tanaman kelapa sawit terhadap air untuk pertumbuhannya. Kadar air tanah mengalami penurunan seiring dengan jumlah curah hujan yang berkurang atau menurun. Hal ini sesuai dengan penelitian Syahadat et al. (2011) yang menyatakan bahwa kadar air tanah tidak hanya dipengaruhi oleh curah hujan dan pertumbuhan biomulsa, akan tetapi juga dipengaruhi faktor lain seperti sifat fisik tanah.

Fluktuasi nilai kadar air tanah tidak hanya ditentukan oleh curah hujan, tetapi juga dipengaruhi oleh proses evapotranspirasi dan penyerapan air di dalam tanah, namun curah hujan yang mengalami penurunan dari minggu sebelumnya dengan nilai kadar air tanah yang meningkat dapat terjadi karena tanah mempunyai kemampuan yang baik dalam menyimpan air. Dengan demikian, masih terdapat simpanan air di dalam tanah akibat curah hujan yang lebih tinggi pada minggu sebelumnya. Curah hujan yang jatuh di lokasi penelitian tidak dapat diresapkan seluruhnya ke dalam tanah. Sebagian dari curah hujan tersebut mengalir

Tabel 1. Rata-rata kadar air tanah pada berbagai jenis biomulsa pada 5, 11, dan 20 MST

\begin{tabular}{lccc}
\hline \multirow{2}{*}{ Jenis biomulsa } & \multicolumn{3}{c}{ Kadar air tanah (\%) } \\
\cline { 2 - 4 } & $5 \mathrm{MST}$ & $11 \mathrm{MST}$ & $20 \mathrm{MST}$ \\
\hline Tanpa biomulsa/vegetasi alami & 26.61 & $31.15 \mathrm{ab}$ & $23.43 \mathrm{c}$ \\
Arachis pintoi & 28.88 & $35.38 \mathrm{a}$ & $27.59 \mathrm{~b}$ \\
Centrosema pubescens & 29.20 & $28.16 \mathrm{~b}$ & $34.15 \mathrm{a}$ \\
Calopogonium mucunoides & 28.26 & $27.95 \mathrm{~b}$ & $33.98 \mathrm{a}$ \\
Pueraria javanica & 28.44 & $29.94 \mathrm{ab}$ & $29.65 \mathrm{~b}$ \\
\hline
\end{tabular}

Keterangan: Angka yang diikuti huruf yang sama pada kolom yang sama menunjukkan tidak berbeda nyata uji lanjut DMRT pada taraf nyata $5 \%$. MST $=$ Minggu Setelah Tanam 
A

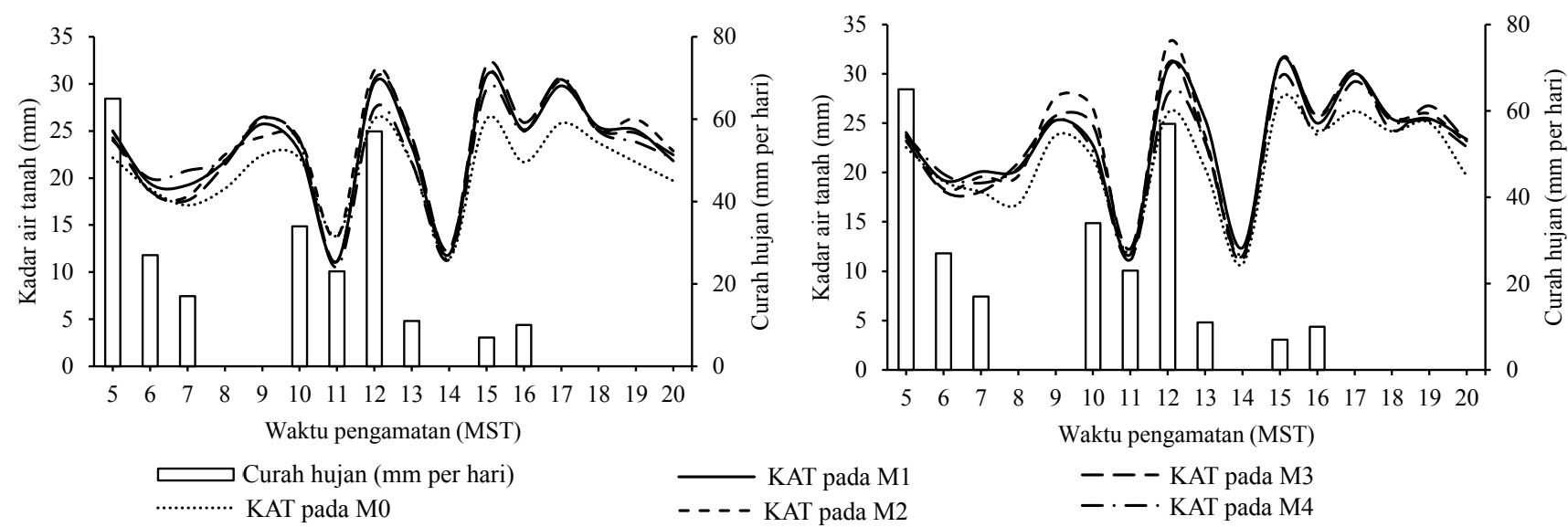

Gambar 1. Hubungan kadar air tanah dengan curah hujan. A) Kedalaman tanah 0-10 cm dan B) Kedalaman tanah 10-20 cm Keterangan: Tanpa biolmulsa/vegetasi alami (M0), Arachis pintoi (M1), Censtrosema pubescens (M2), Calopogonium mucunoides (M3) dan Pueraria javanica (M4)

di permukaan tanah dalam bentuk runoff (Wirasembada et al., 2014). Perubahan penggunaan lahan juga sangat mempengaruhi sifat-sifat fisik tanah sehingga berpengaruh pula pada pergerakan air dalam tanah (Rosyidah dan Wirosoedarmo, 2013).

Nilai kadar air tanah pada perlakuan biomulsa menunjukkan selang nilai yang kecil antar biomulsa (Tabel 2). Nilai kadar air tanah berkisar antara 12.54-38.04\% pada kedalaman tanah $0-10 \mathrm{~cm}$ dan $12.73-39.32 \%$ pada kedalaman tanah 10-20 cm. Nilai kadar air tanah lebih tinggi dibandingkan kapasitas lapang pada analisis awal menunjukkan terdapatnya curah hujan yang tinggi pada saat pengukuran kadar air tanah. Penggunaan biomulsa C. pubescens dapat menahan kadar air lebih tinggi dibandingkan dengan perlakuan lain dengan nilai rata-rata kadar air tanah 27.85\% (0-10 cm) dan 27.97\% (10-20 cm), meskipun tidak berbeda jauh dengan perlakuan biomulsa A. pintoi dan C. mucunoides (Tabel 2). Biomulsa A. pintoi dapat mempertahankan kadar air tanah hingga 27.39\% pada kedalaman $0-10 \mathrm{~cm}$ dan $27.66 \%$ pada kedalaman 10-20 cm. Nilai kadar air tanah tersebut menunjukkan bahwa pemberian biomulsa atau tanaman penutup tanah memberikan pengaruh terhadap ketersediaan air tanah pada pertanaman kelapa sawit. Hasil ini sesuai dengan penelitian Wahyuni et al. (2012a) yang menunjukkan bahwa nilai kadar air tanah pada lapisan bawah lebih tinggi dibandingkan dengan lapisan atasnya.

Selang nilai kadar air tanah pada perlakuan biomulsa lebih besar dibandingkan tanpa biomulsa dapat disebabkan oleh pertumbuhan serta penutupan tanah oleh berbagai biomulsa. Pada kedalaman 10-20 cm tanah lebih mampu memegang air dibandingkan dengan kedalaman 0-10 cm. Kondisi ini menunjukkan bahwa air bergerak menuju lapisan yang lebih dalam pada saat setelah hujan, tetapi akan bergerak ke atas sebagai akibat tarikan akar saat tidak terjadi hujan. Faktor lain yang diduga berpengaruh adalah air pada lapisan atas $(0-10 \mathrm{~cm})$ lebih cepat mengalami evapotranspirasi sehingga kadar air tanahnya lebih rendah

Tabel 2. Selang nilai kadar air tanah dengan perlakuan berbagai jenis biomulsa pada dua kedalaman tanah pada 5-20 MST*

\begin{tabular}{|c|c|c|c|c|c|}
\hline \multirow{2}{*}{ Jenis biomulsa } & \multirow{2}{*}{$\begin{array}{c}\text { Kedalaman } \\
\text { tanah }\end{array}$} & \multicolumn{3}{|c|}{ Kadar air tanah $(\%)$} & \multirow{2}{*}{ Rata-rata } \\
\hline & & Minimum & Maksimum & $\Delta$ & \\
\hline \multirow[t]{2}{*}{ Tanpa biomulsa/vegetasi alami } & $0-10 \mathrm{~cm}$ & 13.60 & 31.29 & 17.69 & 24.82 \\
\hline & $10-20 \mathrm{~cm}$ & 12.73 & 32.60 & 19.87 & 25.11 \\
\hline \multirow[t]{2}{*}{ Arachis pintoi } & $0-10 \mathrm{~cm}$ & 13.24 & 36.69 & 23.45 & 27.39 \\
\hline & $10-20 \mathrm{~cm}$ & 13.90 & 37.24 & 23.34 & 27.66 \\
\hline \multirow[t]{2}{*}{ Centrosema pubescens } & $0-10 \mathrm{~cm}$ & 14.69 & 37.40 & 22.71 & 27.85 \\
\hline & $10-20 \mathrm{~cm}$ & 13.15 & 39.32 & 26.17 & 27.97 \\
\hline \multirow[t]{2}{*}{ Calopogonium mucunoides } & $0-10 \mathrm{~cm}$ & 13.24 & 38.04 & 24.80 & 27.63 \\
\hline & $10-20 \mathrm{~cm}$ & 13.74 & 37.28 & 23.54 & 27.57 \\
\hline \multirow[t]{2}{*}{ Pueraria javanica } & $0-10 \mathrm{~cm}$ & 12.54 & 36.50 & 23.96 & 27.04 \\
\hline & $10-20 \mathrm{~cm}$ & 13.29 & 34.78 & 21.49 & 26.81 \\
\hline
\end{tabular}

Keterangan: *) Nilai rata-rata diperoleh tanpa analisis statistik 
daripada lapisan di bawahnya. Tingginya kehilangan air di lapisan atas dapat juga disebabkan oleh jumlah akar di lapisan atas lebih banyak daripada lapisan bawah sehingga air yang diserap oleh tanaman juga lebih banyak. Penelitian Ariyanti et al. (2016b) menyebutkan bahwa penanaman $N$. biserrata sebagai tanaman penutup tanah pada tanaman kelapa sawit dapat meningkatkan kadar air tanah rata-rata harian. Heryani et al. (2013) pada tanaman cabai rawit menyatakan bahwa air tersedia pada perlakuan mulsa jerami lebih tinggi dibandingkan dengan tanpa mulsa (kontrol).

\section{Kecepatan Penutupan Tanah Berbagai Jenis Biomulsa terhadap Kadar Air Tanah}

Berdasarkan Gambar 2, dapat dilihat bahwa persentase penutupan tanah oleh biomulsa $A$. pintoi cenderung lebih tinggi dibandingkan dengan biomulsa lainnya hingga 9 MST. Biomulsa C. mucunoides mencapai penutupan tanah $100 \%$ pada 14 MST. Dalam penelitian ini tanaman $A$. pinto $i$ mampu menutupi hingga $97.88 \%$ pada 14 MST. Kecepatan penutupan tanah dipengaruhi oleh panjang tanaman, jumlah cabang atau sulur, dan jumlah daun. Penutupan tanah oleh biomulsa dapat mempertahankan kadar air tanah. Semakin cepat penutupan tanah oleh biomulsa, semakin tinggi kadar air yang dapat ditahan oleh biomulsa tersebut. Meskipun hal ini tidak terjadi pada semua pengamatan. Carvalho dan Quesenberry (2012) menyatakan bahwa tanaman $A$. pintoi membutuhkan waktu yang cukup lama untuk tumbuh optimal dan menutupi lahan. Penelitian Sumiahadi (2014) menunjukkan bahwa tanaman $A$. pintoi hanya dapat menutupi sekitar $58 \%$ luasan lahan $0.25 \mathrm{~m}^{2}$ dalam waktu 12 MST. Febrianto dan Chozin (2014) menemukan bahwa penutupan tanah oleh biomulsa $A$. pintoi mencapai $99.61 \%$ dengan jarak tanam $20 \mathrm{~cm} \times 5 \mathrm{~cm}$ pada 90 MST.

\section{Produksi Biomassa berbagai Jenis Biomulsa}

Hasil sidik ragam menunjukkan bahwa produksi biomassa antar jenis biomulsa yang digunakan sebagai

A

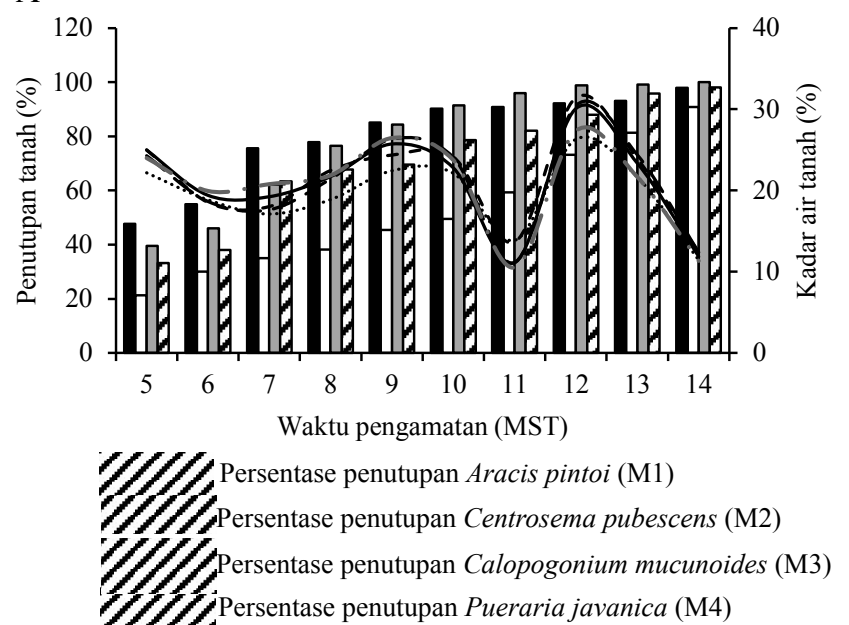

tanaman penutup tanah sangat beragam (Tabel 3). Produksi biomassa diukur dalam bentuk bobot kering. Setiap jenis biomulsa menunjukkan perbedaan produksi biomassa per satuan waktu dan per satuan luasan. Bobot kering biomulsa A pintoi mencapai 1.7 ton ha-1 yang tercapai pada $20 \mathrm{MST}$, sedangkan biomulsa $C$. pubescens mencapai 1.3 ton ha $^{-1}$ dan $P$. javanica sebesar 2.4 ton ha $^{1}$ yang tercapai pada 16 MST. Bobot kering tertinggi terdapat pada biomulsa $C$. mucunoides mencapai 5.4 ton $\mathrm{ha}^{-1}$ yang tercapai pada saat 16 MST. Hasil ini seiring dengan persentase penutupan tanah oleh biomulsa. Semakin tinggi penutupan tanah maka semakin banyak produksi biomassa yang dihasilkan. Penutupan tanah dipengaruhi oleh pertumbuhan biomulsa. Secara keseluruhan produksi biomassa menurun pada 20 MST kecuali biomulsa $A$. pintoi. Hal ini disebabkan oleh pertumbuhan daun tanaman yang tua mulai layu dan gugur setelah 16 MST. Balittan (2004) menyebutkan bahwa $C$. pubescens, $C$. mucuniodes, dan $P$. javanica merupakan tipe tanaman semusim sedangkan $A$. pintoi merupakan jenis tanaman tahunan. A. pintoi sebagai legume tahunan menunjukkan pertumbuhan yang lambat dan toleran kekeringan, meskipun berkembang baik pada tanah lembab yang didukung oleh curah hujan (Santos et al., 2013).

\section{Hubungan Biomassa Berbagai Jenis Biomulsa dengan Kadar Air Tanah}

Produksi biomassa mengalami peningkatan pada setiap pengamatan seiring dengan fluktuasi kadar air tanah pada pertanaman kelapa sawit belum menghasilkan. Hal ini dapat terlihat pada 8, 12, dan 20 MST. Pada 16 MST produksi biomassa tidak berpengaruh terhadap kadar air tanah, produksi biomassa meningkat pada saat kadar air tanah menurun dari minggu sebelumnya (Gambar 3). Hal ini berkaitan juga dengan kondisi curah hujan yang rendah pada 16 MST. Kadar air tanah yang ada dipakai untuk evapotranspirasi pada biomulsa, sehingga pada saat curah hujan rendah kadar air tanah akan berkurang. Gambar 3 memperlihatkan bahwa nilai kadar air tanah berfluktuasi

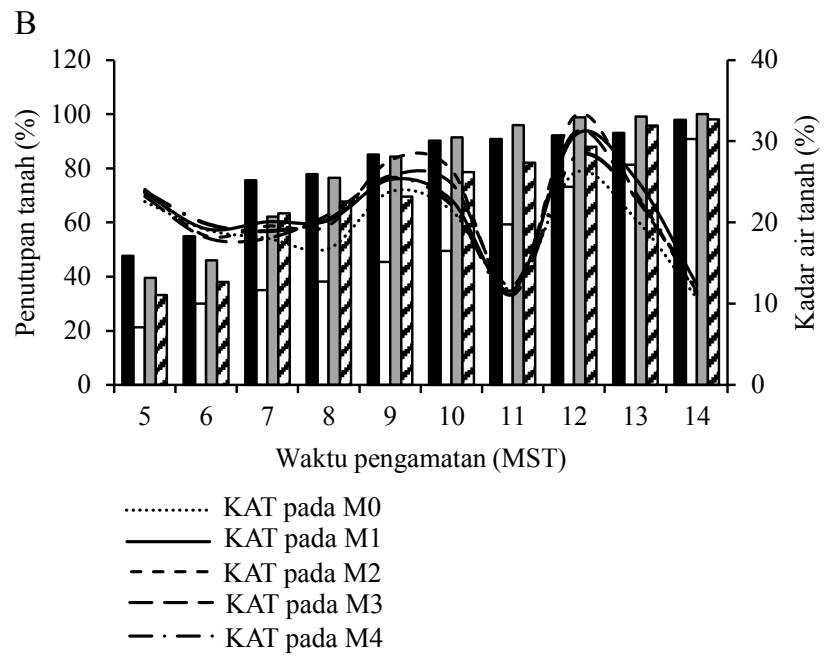

Gambar 2. Perbandingan persentase penutupan tanah berbagai jenis biomulsa dengan kadar air tanah pada dua kedalaman. A) Kedalaman tanah 0-10 cm dan B) Kedalaman tanah 10-20 cm 
Tabel 3. Rata-rata produksi biomassa berbagai jenis biomulsa pada gawangan kelapa sawit

\begin{tabular}{lrrrr}
\hline \multirow{2}{*}{ Jenis biomulsa } & \multicolumn{4}{c}{ Bobot kering $\left(\mathrm{g} \mathrm{m}^{-2}\right)$} \\
\cline { 2 - 5 } & $8 \mathrm{MST}$ & $12 \mathrm{MST}$ & $16 \mathrm{MST}$ & $20 \mathrm{MST}$ \\
\hline Arachis pintoi & $53.74 \mathrm{~b}$ & $66.34 \mathrm{c}$ & $127.01 \mathrm{~b}$ & $170.18 \mathrm{~b}$ \\
Centrosema pubescens & $78.86 \mathrm{~b}$ & $89.59 \mathrm{c}$ & $133.64 \mathrm{~b}$ & $79.61 \mathrm{~b}$ \\
Calopogonium mucunoides & $149.20 \mathrm{a}$ & $401.94 \mathrm{a}$ & $540.71 \mathrm{a}$ & $272.28 \mathrm{a}$ \\
Pueraria javanica & $51.37 \mathrm{~b}$ & $204.87 \mathrm{~b}$ & $240.25 \mathrm{~b}$ & $151.09 \mathrm{~b}$ \\
\hline
\end{tabular}

Keterangan: Angka yang diikuti huruf yang sama pada kolom yang sama menunjukkan tidak berbeda nyata uji lanjut DMRT pada taraf nyata $5 \%$. MST $=$ Minggu Setelah Tanam

setiap minggu. Pada kedalaman yang sama untuk masingmasing perlakuan memiliki nilai kadar air tanah yang berbeda-beda.

Pada 20 MST produksi biomassa biomulsa $A$. pintoi meningkat, tetapi tidak berpengaruh terhadap kadar air tanah. Menurut Winarbawa (2000) kadar air tanah tidak hanya dipengaruhi oleh produksi biomassa atau bobot kering tanaman, tetapi juga dipengaruhi oleh curah hujan dan kondisi tanah. Kehilangan air pada tanaman melalui proses evapotranspirasi dan penyerapan air oleh akar di dalam tanah mengakibatkan nilai kadar air tanah menjadi berkurang dari minggu sebelumnya.
A

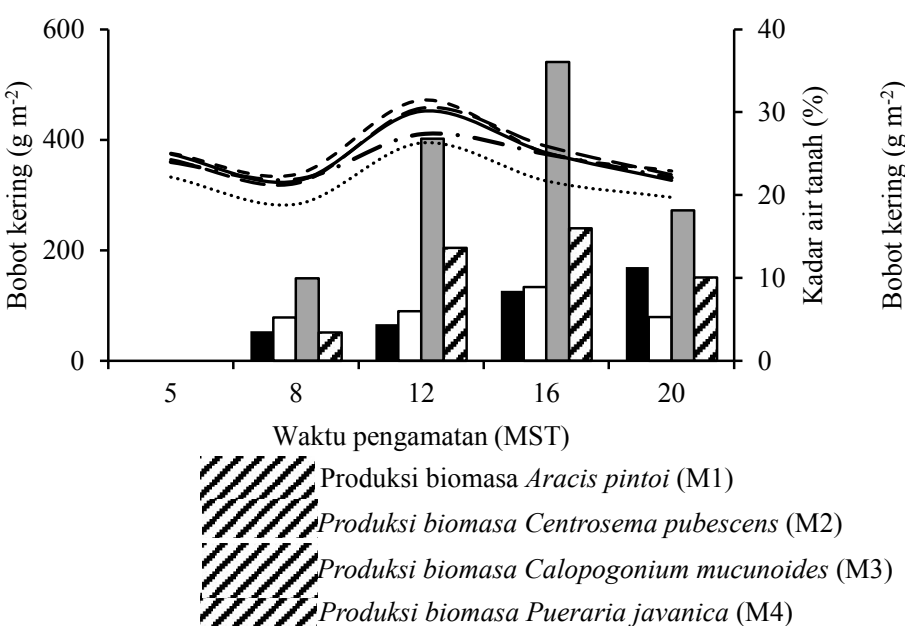

B

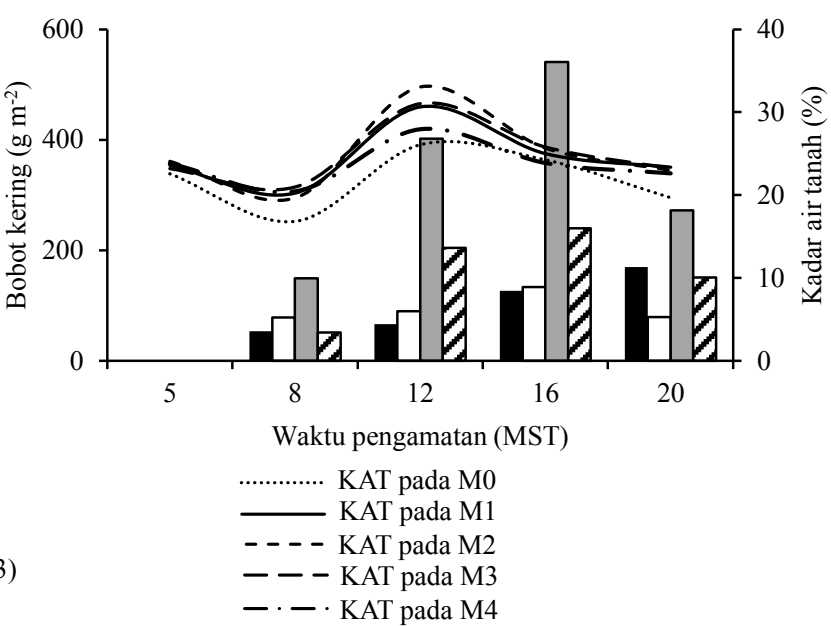

Gambar 3. Perbandingan rata-rata produksi biomasa berbagai jenis biomulsa dengan kadar air tanah pada dua kedalaman. A) Kedalaman tanah 0-10 cm dan B) Kedalaman tanah 10-20 cm

\section{KESIMPULAN}

A. pintoi sebagai biomulsa mempunyai kemampuan penutupan tanah dan menahan air tanah yang tidak berbeda dengan C. pubescens, C. mucunoides dan P. javanica. Kadar air tanah pada kedalaman tanah yang berbeda dipengaruhi oleh ketersediaan air dalam tanah dan vegetasi penutup tanah. A. pintoi dapat mempertahankan kadar air tanah hingga $27.39 \%$ pada kedalaman $0-10 \mathrm{~cm}$ dan $27.66 \%$ pada kedalaman 10-20 cm, meskipun masih lebih rendah dibandingkan $C$. pubescens.

\section{DAFTAR PUSTAKA}

Arsyad, S. 2012. Konservasi Tanah dan Air. IPB Press, Bogor.
Ariyanti, M., S. Yahya, K. Murtilaksono, Suwarto, H.H. Siregar. 2016a. Water balance in oil palm plantation with ridge terrace and Nephrolepis biserrata as cover crop. J. Trop. Crop Sci. 3:35-41.

Ariyanti, M., S. Yahya, K. Murtilaksono, Suwarto, H.H. Siregar. 2016b. Pengaruh tanaman penutup tanah Nephrolepis biserrata dan teras gulud terhadap aliran permukaan dan pertumbuhan kelapa sawit (Elaeis guineensis Jacq.). J. Kultivasi 15:121-127.

Asbur, Y., S. Yahya, K. Murtilaksono, Sudradjat, E.S. Sutarta. 2016. The rules of Asystasia gangetica (L.) $\mathrm{T}$. Anderson and ridge terrace in reducing soil erosion and nutrient losses in oil palm plantation in South Lampung, Indonesia. J. Trop. Crop Sci. 3:49-55. 
Asbur, Y., M. Ariyanti. 2017. Peran konservasi tanah terhadap cadangan karbon tanah, bahan organik dan pertumbuhan kelapa sawit (Elaeis guineensis Jacq.). J. Kultivasi 16:402-411.

[Balittan] Balai Penelitian Tanah. 2004. Kacang hias (Arachis pintoi) pada usaha tani lahan kering. Pusat Litbang Tanah dan Agroklimat, Bogor.

Carvalho, M.A., K.H. Quesenberry. 2012. Agronomic evaluation of Arachis pintoi (Karp. and Greg.) germplasm in Florida. Arch. Zootec. 61:19-29.

Chozin, M.A., J.G. Kartika, R. Baharudin. 2014. Penggunaan kacang hias (Arachis pintoi) sebagai biomulsa pada budidaya tanaman tomat (Lycopersicon esculentum M.). J. Hort. Indonesia 4:168-174.

Farni, Y., A.R. Arsyad, H. Junedi. 2012. Pemupukan kelapa sawit berdasarkan potensi produksi untuk meningkatkan hasil tandan buah segar (TBS) pada lahan marginal Kumpeh. J. Penelitian Univ. Jambi 14:29-36.

Febrianto, Y., M.A. Chozin. 2014. Pengaruh jarak tanam dan jenis stek terhadap kecepatan penutupan Arachis pintoi Krap. \& Greg. sebagai biomulsa pada pertanaman tomat (Licopersicon esculentum M.). Bul. Agrohorti. 2:37-41.

Hamdani, J.S. 2009. Pengaruh jenis mulsa terhadap pertumbuhan dan hasil tiga kultivar kentang (Solanum tuberosum L.) yang ditanam di dataran medium. J. Agron. Indonesia 37:14-20.

Heryani, N., B. Kartiwa, Y. Sugiarto, T. Handayani. 2013. Pemberian mulsa dalam budidaya cabai rawit di lahan kering: dampaknya terhadap hasil tanaman dan aliran permukaan. J. Agron. Indonesia 41:147-153.

Nita, I., E. Listyarini, Z. Kusuma. 2014. Kajian lengas tersedia pada toposekuen lereng utara Gunung Kawi Kabupaten Malang Jawa Timur. J. Tanah Sumberdaya Lahan 1:49-57.

Pasaribu, H., A. Mulyadi, S. Tarumun. 2012. Neraca air di perkebunan kelapa sawit di PPKS sub unit Kalianta Kabun Riau. J. Ilmu Lingkungan 6:99-113.

Rosyidah, E., R. Wirosoedarmo. 2013. Pengaruh sifat fisik tanah pada konduktivitas hidrolik jenuh di 5 penggunaan lahan (studi kasus di Kelurahan Sumber Sari Malang). Agritech. 33(3):340-345.

Santos, J.C.F., A.J. Cunha, F.A. Ferreira, R.H.S. Santos, N.S. Sakiyama, P.C. Lima. 2013. Cultivation of perennial herbaceous legumes in weed management in coffee plantation on the cerrado. J. Agric. Sci. Tech. 3:420428.

Santosa, E., I.M. Stefano, A.G. Tarigan, A. Wachjar, S. Zaman, H. Agusta. 2018. Tree-based water footprint assessment on established oil palm plantation in North Sumatera. J. Agron. Indonesia 46:111-118.

Sumiahadi, A. 2014. Keefektifan biomulsa Arachis pintoi Karp. \& Greg. untuk konservasi tanah dan pengendalian gulma pada pertanaman jagung di lahan kering. Tesis. Sekolah Pascasarjana. Institut Pertanian Bogor. Bogor.

Sumiahadi, A., M.A. Chozin, D. Guntoro. 2016. Evaluasi pertumbuhan dan perkembangan Arachis pintoi sebagai biomulsa pada budidaya tanaman di lahan kering tropis. J. Agron. Indonesia 44:98-103.

Syahadat, P., S.D. Tarigan, K. Murtilaksono. 2011. Karakteristik hantaran hidrolik jenuh tanah pada perkebunan kelapa sawit, PTPN VII Lampung Selatan. J. Tanah. Lingk. 13:58-62.

Wahyunie, E.D., D.P.T. Baskoro, M. Sofyan. 2012a. Kemampuan retensi air dan ketahanan penetrasi tanah pada sistem olah tanah intensif dan olah tanah konservasi. J. Tanah. Lingk. 14:73-78.

Wahyunie, E.D., N. Sinukaban, B.S.D. Damanik. 2012 b. Perbaikan kualitas sifat fisik tanah menggunakan mulsa jerami padi dan pengaruhnya terhadap produksi kacang tanah. J. Tanah Lingk. 14:7-13.

Wakhid, R., S. Widodo, M. Pudjojono. 2012. Pengaruh pemberian naungan dan mulsa terhadap kadar air tanah dalam produksi tanaman bawang merah pada musim penghujan. Agrotek. 6:51-58.

Widodo, I.T., B.D. Dasanto. 2010. Estimasi nilai lingkungan perkebunan kelapa sawit ditinjau dari neraca air tanaman kelapa sawit (studi kasus: perkebunan kelapa sawit di Kecamatan Dayun, Kabupaten Siak, Propinsi Riau). J. Agromet. 24:23-32.

Winarbawa, S. 2000. Pengaruh kadar air tanah terhadap pertumbuhan dan produksi dua tipe Kapolaga Sabrang. Bul. Agron. 28:1-8.

Wirasembada, Y.C., B.I. Setiawan, S.K. Saptomo. 2014. Pengembangan konsep zero runoff system (ZROS) untuk optimalisasi kadar air tanah pada lahan perkebunan non irigasi. J. Keteknikan Pertanian 2:125-132. 